\title{
The evolution of African plant diversity
}

\author{
H. Peter Linder * \\ Institute of Systematic Botany, University of Zurich, Zurich, Switzerland
}

\section{Edited by:}

Toby Pennington, Royal Botanic

Garden Edinburgh, UK

Reviewed by:

Harald Schneider, Natural History

Museum, UK

Thomas Couvreur, Institut de

Recherche pour le Développement,

Cameroon

David J. Harris, Royal Botanic

Garden Edinburgh, UK

\section{${ }^{*}$ Correspondence:}

H. Peter Linder, Institute of

Systematic Botany, University of

Zurich, Zollikerstrasse 107, CH-8008

Zurich, Switzerland

e-mail:peter.linder@systbot.uzh.ch
Sub-Saharan Africa includes some 45,000 plant species. The spatial patterns of this diversity have been well explored. We can group the species into a set of biogeographical regions (largely co-incident with regions defined for terrestrial vertebrate groups). Furthermore, we know that the diversity is unevenly distributed, with southern Africa (especially the south-western tip) disproportionally species rich, while the West African interior is disproportionally species poor. However, the origins of this diversity have only been explored for two anomalous African Floras (the Tropic-alpine Flora and the Cape Flora), whereas the origins of the diversity of the other floras are still unknown. Here I argue that six floras, with distinct geographical centers, different extra-African affinities, ages of radiation and radiation rates, can be delimited: the Austro-temperate, Tropic-alpine, Lowland forest, Tropic-montane, Savanna and Arid Floras. The oldest flora may be the Lowland forest Flora, and the most recent is the Tropic-alpine, which probably evolved during the Plio-Pleistocene on the summits of the East Africa volcanoes. My results suggest that the most rapidly radiating flora is the Austro-temperate Flora, while the other floras are all diversifying at more or less the same rate, this is also consistent with the current massive species richness in this flora (about half of the African species richness). The Austro-temperate Flora appears to be related to the floras of the other southern continents, the Tropic-alpine Flora to that of the Northern Hemisphere, and the four tropical floras to the tropical regions of the other continents, consistent with the theory of phylogenetic niche conservatism. Current African diversity may be the result of the sequential adding of new floras to the continent. Possibly the species poverty especially of the Lowland forest Flora may be the result of the spread of $\mathrm{C}_{4}$ grasslands and associated regular fires.

Keywords: Africa, biogeography, Cenozoic, diversification rates, extinction, fire, floras, savanna

\section{INTRODUCTION}

A central theme in evolutionary biology is the evolution of diversity. This can be addressed at many scales. At the most detailed level it deals with the evolution of genetic diversity within populations, and at the broadest level it addresses the evolution of differences in species richness and composition among continents. The time-scales also vary from hours in the case of bacterial diversification to geological time for continental differentiation. Africa, symmetrically astride the equator, is rich in biodiversity paradoxes. The Sahara, the world's largest desert, is arguably the largest extremely species-poor area on the planet. At the other end of the continent is the Cape flora, arguably the globally most species rich temperate flora. Similarly, the extensive species-poor Sahelian semi-desert of West Africa is counterpoised to the worlds richest semi-desert flora of the succulent karoo. The very extensive species-poor savannas are host to one of the richest mammal faunas. The ice-desert of the worlds highest free-standing mountain (Mt Kilimanjaro) contrasts with salt-desert of the Afar depression, the second deepest dry place below ocean level (after the Dead Sea). We do not yet have a narrative explaining the origins of this African diversity.
Africa includes approximately 45,000 plant species in 29 million $\mathrm{km}^{2}$ (Klopper et al., 2007), compared to c. 90,000 in 17.84 million $\mathrm{km}^{2}$ in South America and c. 42,000 species in 3 million $\mathrm{km}^{2}$ in Malesia (Davis, 1995). Furthermore, this diversity is distributed very unevenly across the continent (Figure 1). Whereas the central Sahara is probably one of the largest, maximally species-poor non-glaciated regions of the planet, the south western tip of the continent at Cape Town is one of the most species rich (Manning and Goldblatt, 2013; Snijman, 2013), and houses some $25 \%$ of all African species. There is a remarkable gradient in diversity from the Sahara southwards to the West African coast, peaking in Cameroun-Gabon area. The escarpments of central and southern Africa are also much more species rich than the central plateau, and the eastern escarpment is richer than the western escarpment. These patterns are based on analysis of 5881 species analyzed at a $1^{\circ}$ level (Linder, 2001), but the broad pattern matches the diversity estimates based on whole floras (Küper et al., 2004; Mutke and Barthlott, 2005).

Endemism richness (Kier et al., 2009), defined as the proportion of range restricted species, shows somewhat different patterns, with the northern half of the continent with isolated 


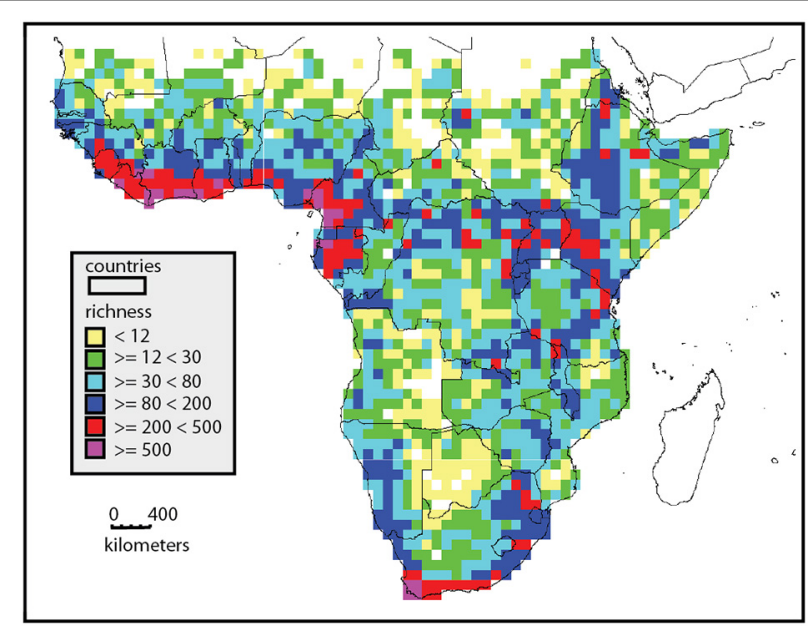

FIGURE 1 | Distribution of species richness in sub-Saharan Africa, based on analysis of $\mathbf{5 8 8 1}$ species mapped to a $\mathbf{1}^{\circ} \mathbf{g r i d}$. Richness is color coded, yellow squares are most species poor and purple most species rich. This illustrates the high richness of the West African coast, the East African uplands, and the southern tip of the continent.

patches of endemism richness, usually associated with mountains (Figure 2). The areas between these patches are very low in endemism richness. Africa south of $10^{\circ}$ has a much higher background level of endemism richness (Linder, 2001), and the Eastern Arc of East Africa is generally high in endemism richness. This reaches an extreme in the Cape flora, with some 70\% endemism to the winter rainfall region (Snijman, 2013). Areas of high endemism richness are usually also areas with a high turnover in species composition, as many species have narrow distribution ranges. The center of the continent is species poor, with a low level of endemism richness, and so with a low level of species composition turnover.

The spatial changes in species composition have been used to regionalize the African flora. The "phytochorological" classification of White (1983) was based on the comparison of lists of species from across Africa, but without a numerical analysis. White's highly influential system recognized regional centers of endemism, separated by transitional zones, but did not arrange these hierarchically. There have been several attempts to regionalize the flora objectively (Denys, 1980; Linder et al., 2005, 2012b). The last compared the plant patterns with those of several groups of vertebrates (mammals, birds, snakes and frogs) and found a surprisingly high degree of congruence. Based on this a new regionalization of the African biota was proposed (Figure 3).

Three disjunct distribution tracks have been described for Africa. The first described is the "arid track" which links the semi-desert of the Kalahari with NE Africa, and which is manifested both by shared, disjunct species and by sister species (De Winter, 1966, 1971; Verdcourt, 1969; Thiv et al., 2011; Bellstedt et al., 2012). This can be extended to the African West Coast at Mauritania and to the semi-arid Sahelian regions, encompassing the arid margins of the continent, the so-called "Rand Flora" (Jürgens, 1997; Sanmartin et al., 2010). The second track links the mesic evergreen forests and grasslands of the tropic-montane

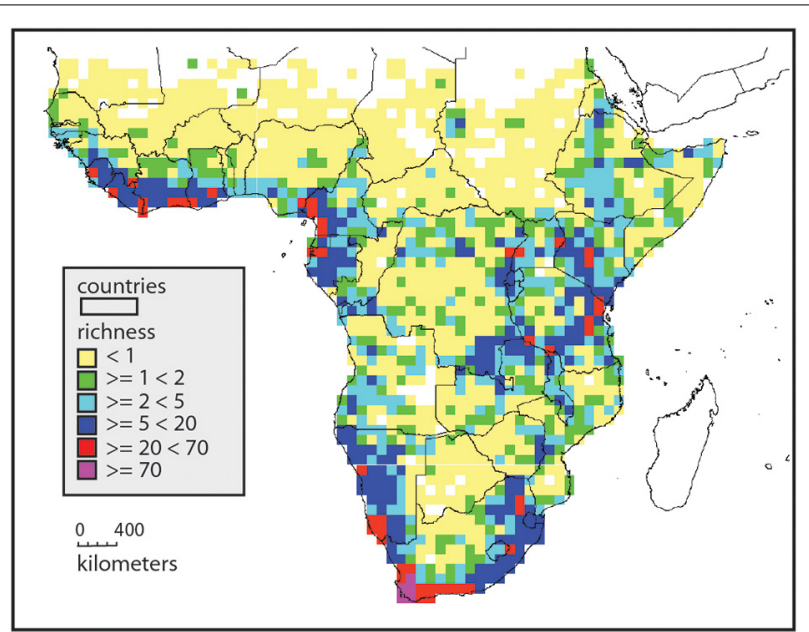

FIGURE 2 | Endemism richness in Africa, based on the distributions of $\mathbf{5 8 8 1}$ species. This is the sum of species per grid, but each occurrence is inversely weighted by its distribution range. Widespread species contribute little to the endemism richness of a gridcell, whereas species with small ranges contribute much. Yellow indicates grids with few, and mostly widespread species, and red and purple indicates grids with numerous, narrowly distributed species. This picks out the centers of endemism and richness more effectively than simple richness.

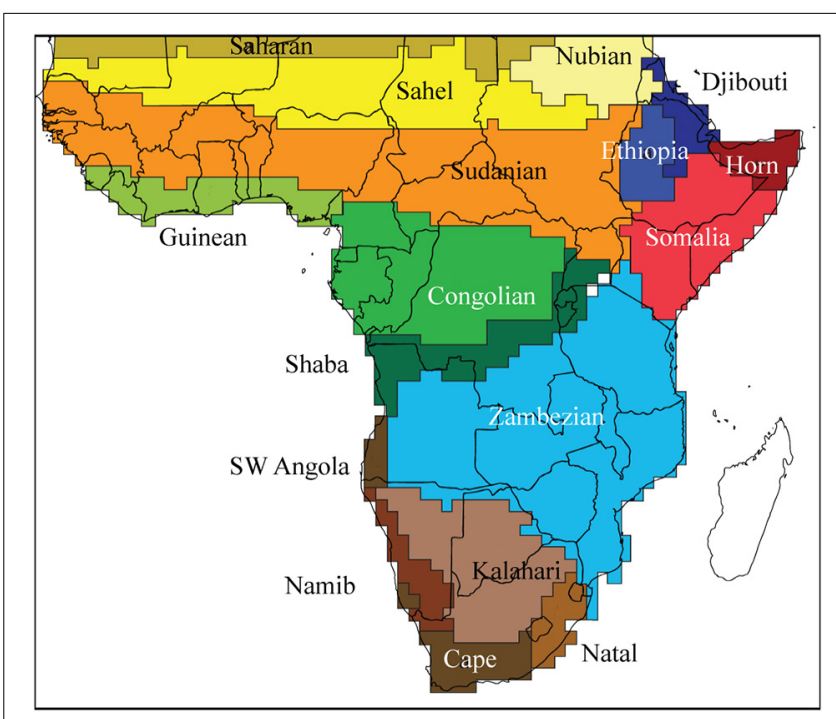

FIGURE 3 | Regionalization of Africa, based on presence data at a $\mathbf{1}^{\circ}$ scale for a sample of plant species, and all mammal, bird, frog, and snake species. This recognizes several broad regions (Saharan, Sudanian, Congolese, Horn of Africa, Zambesian, and Southern African) with most subdivided into smaller clusters (Linder et al., 2012b).

regions across Africa. This "Afromontane" track was regarded by White (1978) as a floristic, chorological region, but subsequent numerical analyses failed to retrieve it (Linder, 1998; Linder et al., 2005). This is linked by several widespread species, and also by a numerous genera largely restricted to this region, and has received much attention to date (Wickens, 1976; Linder, 1990; Griswold, 1991; Grimshaw, 2001; Galley et al., 2007). The third disjunction 
is between the rainforests of West and Central Africa and of the East African coastline, often with closely related species (Faden, 1974; Couvreur et al., 2008). These forests are thought to be vicariant, with the disjunction pre-dating the African Miocene doming that resulted in the Rift Valleys and the arid East African interior.

I ask how the current diversity (patterns of richness, regionalization and tracks) of the sub-Saharan African flora (south of about $22^{\circ}$ North) evolved, and address this by analysing the evolutionary history of a selection of African clades. In order to be able to synthesize the individual histories of numerous clades, I group the clades into floras. I define a flora as a group of clades which (a) are largely found in the same area, (b) have largely the same extra-Africa geographical affinities, (c) share a diversification history, and (d) have a common maximum age. This implies that in any given area, several floras can be present, and that any given flora can be geographically disjunct or even fragmented. Floras can also be linked to a limited number of vegetation types. I use these histories to determine when each flora, and so its associated vegetation types, evolved in Africa. I explore the diversification rates in each flora. I ask where, outside Africa, the most closely related clades are found. Finally, I synthesize from these a scenario postulating the evolutionary history of the African flora.

\section{MATERIALS AND METHODS GEOGRAPHICAL PATTERNS}

One of the attributes of a flora is that it occupies a discrete geographical area or areas, consequently the members of a flora can be identified by a shared geographical range. These taxa could be species. However, if a flora also contains evolutionary history, then we should cluster groups of related species or clades (e.g., "Cape clades," Linder, 2003). This could be especially important in floras which are disjunct, and/or which have at least some allopatric species replacement [e.g., in the Tropic-montane Flora (Linder et al., 2012b), the Lowland forest Flora (Faden, 1974), or the Cape flora (Weimarck, 1941)]. This could be incorporated by weighting shared presence by phylogenetic relatedness, but a much simpler albeit cruder method is to use taxonomy as an indication of relatedness, by for example using genera or families. Here I clustered the genera on their shared geographical regions, based on the assumption that each genus is restricted to one flora. This assumption is, however, often violated, especially in large genera, which are often found in several quite distinct floras. This can lead to some strange assignments of genera to floras.

I used the species distribution dataset which was compiled at the Nees Institute, University of Bonn, in the context of BIOTA Africa project together with several external partners. For more details about the dataset and a full acknowledgement of all contributors please refer to Linder et al. (2005) and Küper et al. (2006). This data set includes the distribution data, scored as presence to a $1^{\circ}$ grid, for 5881 species in 1125 genera. These taxa were selected as they had been recently revised, and the distribution data had consequently been verified. These data were simplified to genera, with the number of species per genus in each grid cell summed. I used the checklist compiled and maintained by the
African Plants Database (http://www.ville-ge.ch/musinfo/bd/cjb/ africa/recherche.php, accessed June 2013) (Klopper et al., 2006) to obtain an estimate of the number of species in each genus, and used this list to filter out all genera with less than $50 \%$ of the species present in the Bonn list. This left 331 genera and 3660 species. From this dataset all genera found in fewer than four grid cells, and all grid cells with fewer than five genera, were filtered out, as small numbers in cells can lead to aberrant results. The final database included 309 genera (of the 3802 sub-Saharan genera (Klopper et al., 2007) and 1378 grid cells.

Genera were clustered on the basis of shared distribution ranges. The distances between the genera was determined with $\beta_{\text {sim }}$, which does not take shared absences into account. Because it estimates the proportion of shared species between the two entities that are being compared, for the entity with the smaller number of species, it is also not distorted by a large difference in species richness among the entities (Kreft and Jetz, 2010). The resultant distance matrix was clustered using UPGMA. All analyses were done in R ( R Development Core Team, 2012), using the packages "vegan" (Oksanen et al., 2012), "mass" (Venables and Ripley, 2002) and "cluster" (Maechler et al., 2011). Generic presence was treated as presence/absence, due to the absence of a suitable approach which combines the attributes listed above, with a weighting by the proportion of genus in the region. The distance matrix obtained with the $\beta_{\text {sim }}$ algorithm was also ordinated using principal coordinates analysis (PCoA).

\section{AGE AND EXTRA-AFRICAN AFFINITIES OF THE FLORA}

In order to establish the age of each flora, where its closest sister taxa are found, and what its diversification rate was, I searched the literature for all phylogenies for which the following information was available: the crown age of the clade, the number of species in the flora in which it occurs; and the geographical area of the sister clade. In total 57 clades were used (Supplementary materials). Each clade, or part of a clade, was assigned to one or more African floras. Each crown age was critically compared to available information to check that the indicated ages are consistent with the rest of the literature.

The possible floras had to be postulated prior to the analysis. I used the four floras detected in the geographical analysis, as well as two additional possible floras (the Arid Flora, and the Tropic-alpine Flora) which the geographical analysis could not detect.

\section{SPECIES ACCUMULATION PATTERNS}

Ideally, diversification rates are inferred from species-level dated phylogenies. However, very few such phylogenies are available for the African flora, consequently I used simpler and much cruder methods to determine whether the diversification patterns in the six floras are the same. I built a general linear model in SPSS v. 19 , with species richness of each clade as response variable, and using the age of the clade, and flora membership, source area, and growthform (herbaceous $=1$, woody $=2$, succulent $=3$, softly woody $=4$, and geophytes $=5$ ), as predictor variables. To obtain homogenous variances the response variable was $\log (10)$ transformed. I used the same 57 clades that were used in the age and source analysis. 


\section{RESULTS}

\section{GEOGRAPHICAL PATTERNS}

The geographical analyses suggest the recognition of four African floras: Savanna, Tropic-montane, Lowland forest and Austrotemperate. However, these are not clearly separated. Most distinct are the heathland genera of the Austro-temperate Flora from the lowland forest genera, with tropic-montane and savanna taxa forming intermediate clusters (Figures 4, 5). Thirty-seven genera were not assigned, as they linked into the phenogram below the cut-off for the four groups (unshaded genera in Figure 4), and in the PcoA they are centered, more or less co-incident with the tropic-montane genera.

\section{EXTRA-AFRICAN AFFINITIES OF THE FLORA}

For all floras except the Tropic-alpine, the most common regional source is Africa (Table 1), indicating substantial within-African diversification. This indicates geographical rather than ecological control over the source areas of clades in a flora. However, the extra-African affinities show a strong ecological influence. Lowland forest and savanna clades have their strongest affinities to South America and Asia, which also host tropical forests and savannas. The Austro-temperate Flora is strongly recruited from Australia and only to a minor extent from Eurasia. The tropicalpine clades show a strong connection to Eurasia and to a lesser extent to South America, but none to Australia. This suggests that the Austro-temperate Flora can be regarded as a "southern temperate flora" with a close relationship to the flora of Australia, the Tropic-alpine Flora as a "northern temperate flora" with a close connection to the floras of Europe and the Himalaya. Lowland forest, Arid and Savanna Floras show a linkage to the tropical floras of South America and Asia.

\section{AGES OF FLORAS}

The oldest African clades are found in the Lowland forest Flora (Annonaceae, Moraceae and Sapotaceae), these date to the Cretaceous (Figure 6). The Austro-temperate and Arid Floras date from the Paleogene, and especially in the Austro-temperate Flora many clades originated in the Eocene. The oldest savanna and tropic-montane clades date from the earliest Miocene, while the oldest tropic-alpine clades are from Late Miocene. In three cases the first clades to be assigned to a flora are substantially older than the next oldest (Zygophylloideae in the Arid Flora, Restionaceae in the Austro-temperate Flora, and Moraceae in the Lowland forest Flora). The temporal co-occurrence of many clades after that does give a sense that there is a maximum age to a flora, and there is continuous recruitment into a flora.

\section{DIVERSIFICATION RATE}

The optimal model which predicts the number of species per clade includes the median crown age, the growth form, the source area and the flora to which it belongs and explains $47 \%$ of the variation (Table 2). Evaluation of the parameter estimates shows that whereas all growth forms are significant different $(p<0.05)$, only the Austro-temperate Flora is significantly different from the other four floras. Disentangling the floras based on the mean crown ages of the clades (Figure 7) indicates that overall the

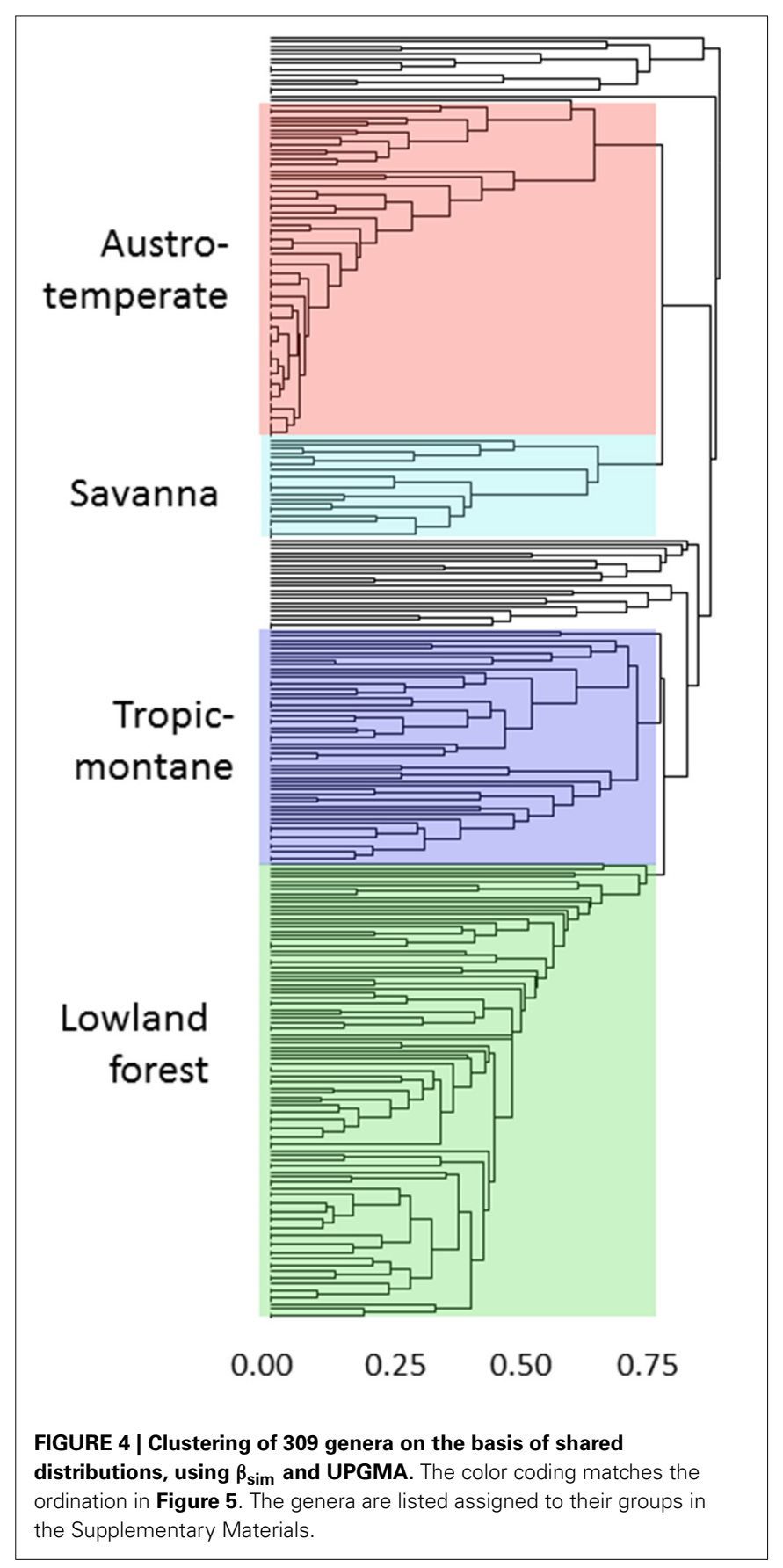

Austro-temperate Flora has a higher diversification rate than the other African floras.

\section{DISCUSSION}

\section{CAVEATS}

This first attempt to infer the evolutionary history of the African flora is based on a number of simplifying assumptions which might affect the results. The search for geographical patterns based on genera assumes that each genus is restricted to a single flora. This might apply to most genera, but there are a number of cases of ecologically (and so be implication also 


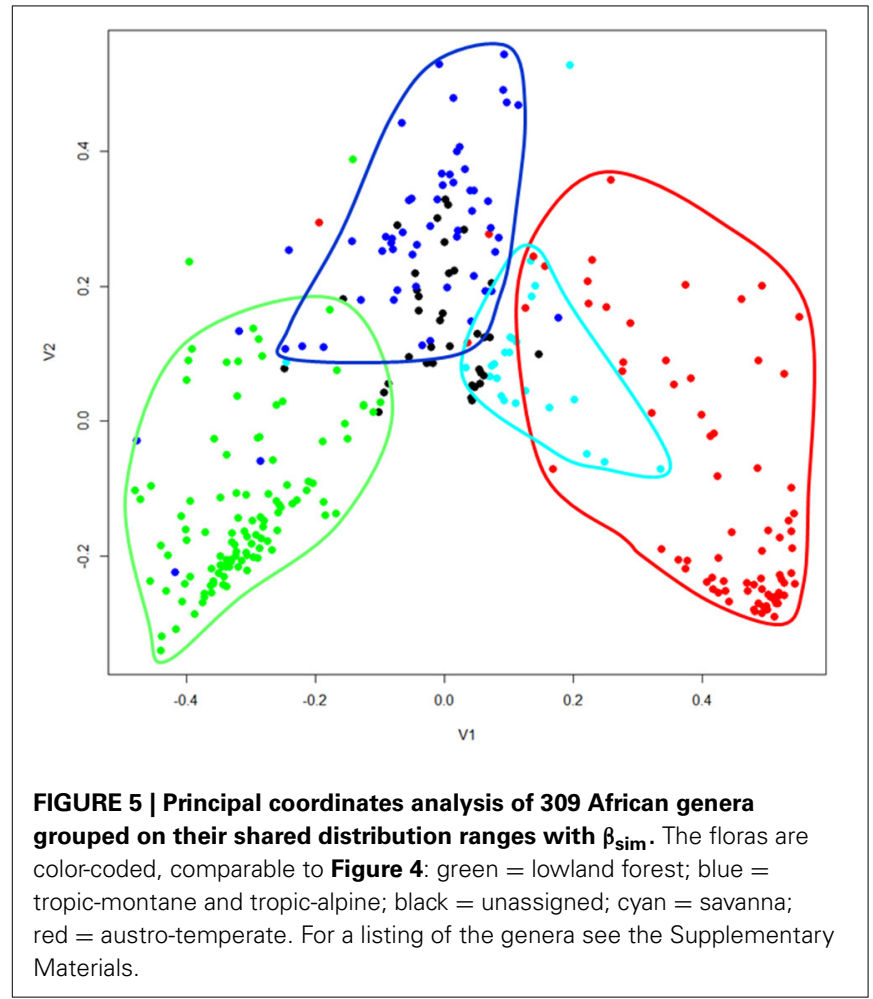

Table 1 | Geographical areas (simplified to continents) of the sister clades of African clades typical of Lowland forest, Arid, Austrotemperate, Savanna, Tropic-montane, and Tropic-alpine Floras.

\begin{tabular}{lccccccc}
\hline & Africa & $\begin{array}{c}\text { South } \\
\text { America }\end{array}$ & Australia & Asia & Eurasia & Totals \\
& \multicolumn{2}{c}{} & $\mathbf{2}$ & 0 & $\mathbf{1}$ & 0 & 9 \\
\hline Lowland forest & 6 & $\mathbf{1}$ & 0 & $\mathbf{1}$ & 0 & 8 \\
Savanna & 6 & 0 & 0 & $\mathbf{2}$ & 0 & 4 \\
Arid & 2 & 1 & $\mathbf{8}$ & 0 & 2 & 16 \\
Austro-temperate & 5 & 0 & 0 & $\mathbf{1}$ & $\mathbf{1}$ & 3 \\
Tropic-montane & 1 & 0 & 0 & $\mathbf{3}$ & $\mathbf{3}$ & 8 \\
Tropic-alpine & 2 & 0 & 8 & 7 & 5 & \\
\hline Totals & 6 & 4 & & & &
\end{tabular}

The values in the cells refer to the number of clades (Supplementary Materials). Highest extra-African ranking areas are shaded red, next come green shaded areas, and least common sister-areas are shaded yellow.

floristically) widespread genera. For example, both Acridocarpus (Malpighiaceae) and Coccinia (Cucurbitaceae) are found in forests, savanna and seasonally arid vegetation (Davis et al., 2002; Holstein and Renner, 2011). Similar shifts have also been documented in Euphorbia, albeit without the forest component (Bruyns et al., 2011; Peirson et al., 2013). In Euphorbia many of the shifts occurred in parallel between the subgenera, often also associated with a parallel evolution of succulence. Dorstenia (Moraceae) is an example of a typical forest understory herb which has also spread into arid habitats, with $D$. gigas a succulent-stemmed shrub in the seasonally arid vegetation of

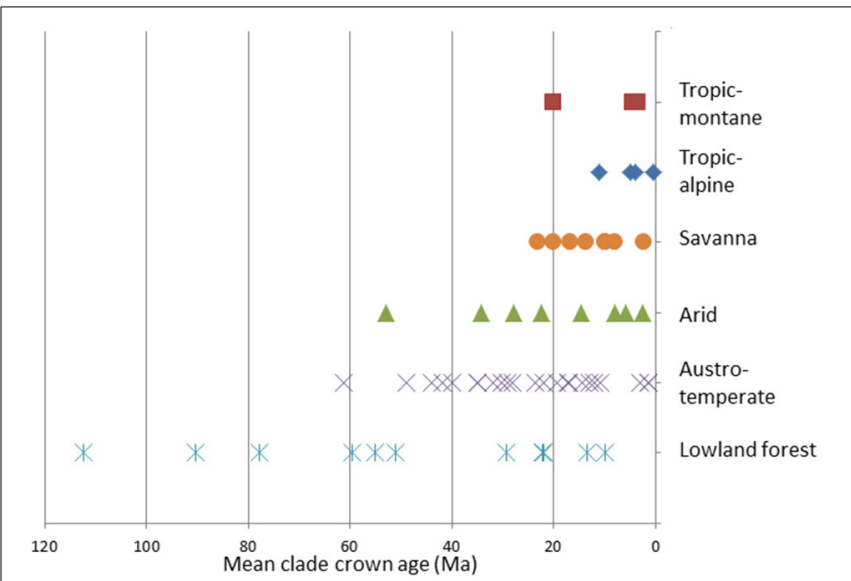

FIGURE 6 | The mean ages of the clades assigned to the African floras.

Table 2 | Results of a general linear model with the log species richness of each clade as response variable, and the mean crown age, the flora, growth form and source region.

\begin{tabular}{lcccrc}
\hline Source & $\begin{array}{c}\text { Type III sum } \\
\text { of squares }\end{array}$ & $\boldsymbol{d f}$ & $\begin{array}{c}\text { Mean } \\
\text { square }\end{array}$ & $\boldsymbol{F}$ & Sig. \\
\hline Corrected model & $15.517^{\mathrm{a}}$ & 13 & 1.194 & 2.939 & 0.004 \\
Intercept & 9.573 & 1 & 9.573 & 23.571 & 0.000 \\
Growth form & 4.997 & 4 & 1.249 & 3.076 & 0.026 \\
Crown age & 4.378 & 1 & 4.378 & 10.779 & 0.002 \\
Extra-African continent & 4.673 & 4 & 1.168 & 2.876 & 0.034 \\
Flora & 5.720 & 4 & 1.430 & 3.521 & 0.014 \\
Error & 17.464 & 43 & 0.406 & & \\
Total & 188.419 & 57 & & & \\
\hline Corrected total & 32.981 & 56 & & & \\
\hline${ }^{2}=0.470$ (Adjusted $\left.R^{2}=0.310\right)$. & & & &
\end{tabular}

Socotra (Misiewicz and Zerega, 2012). These genera could result in obscuring the differences among the floras.

The small number of tropical African clades available for analysis means that the results are perforce tentative, and this applies to both the age of the floras as well as to the assessment of their sister areas. This applies particularly to the Savanna and the Arid Floras. Similarly, estimating the diversification rate from only the crown age and the number of extant species is a very crude approach, which assumes that the diversification rates have been more or less constant. Mixed rates cannot be detected with these methods, and this can lead to the underestimating of diversification rates in nested radiations. Nonetheless, the results obtained are consistent with other information, suggesting that the overall patterns might be correct.

\section{HOW MANY AFRICAN FLORAS?}

It is evident that the floristic diversity of Africa is the product of a complex amalgam of several floras. Geographical analysis suggests four floras: an Austro-temperate Flora and three tropical floras: Lowland forest, Savanna and Tropic-montane Floras. Although some regions are strongly dominated by specific floras, 


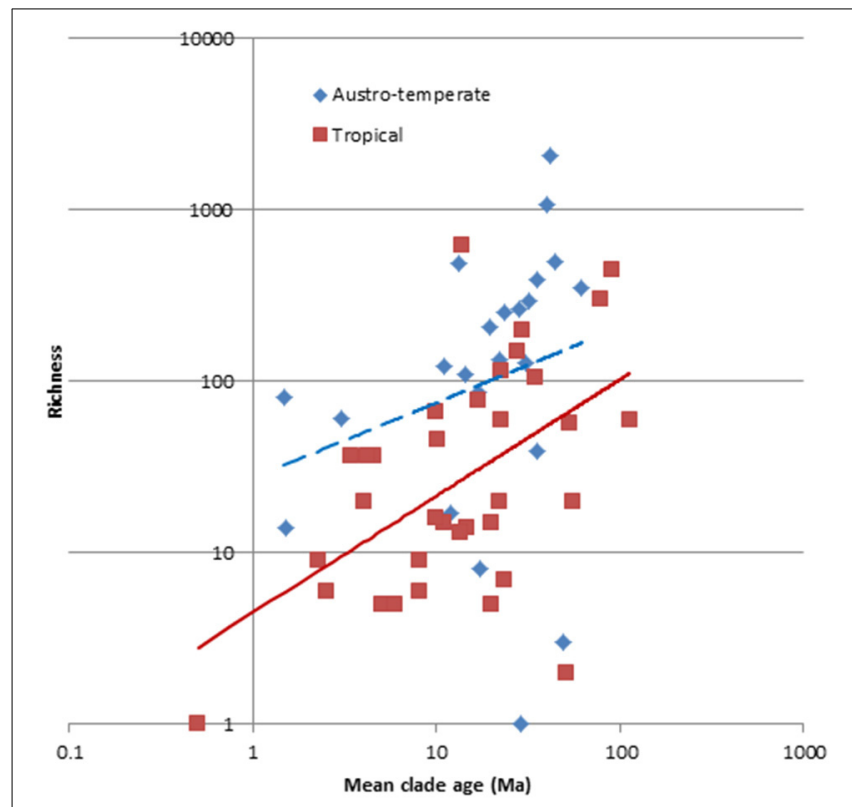

FIGURE 7 | Species richness of 61 clades of the African flora, plotting against their crown age. Color code: red $=$ tropical, blue $=$ austro-temperate. The austro-temperate clades have more species than the tropical clades for their age.

other regions contain elements of several floras, leading to geographical mixtures. Similarly, in many cases the assumption of a genus being restricted to one flora is violated, leading to genera that cannot be confidently placed to any flora. In addition, there are probably two more floras, not detected by the geographical analysis. There is most likely an "Arid Flora," centered in the Horn of Africa, with a secondary center is south-western Africa (Jürgens, 1997). This may have remained undetected because it was not adequately sampled due to the deletion of speciespoor grids. Filtering out cells with few species may have removed many cells from Somalia, north-east Kenya and the Kalahari in which the Arid Flora is well represented. There is also a Tropic-alpine Flora (Hedberg, 1957, 1965), this could not be detected because it is completely geographically embedded in the Tropic-montane Flora.

Investigation of extra-African distribution ranges of closely related clades indicates three groups of floras: a north temperate group (the Tropic-alpine Flora), a south temperate group (the Austro-temperate Flora), and a tropical group (Lowland forest, Savanna and Arid Floras). The Tropic-montane Flora seems to have mixed affinities. The largely north temperate elements in the Tropic-alpine Flora have long been known, and were first systematically documented by Hedberg (1965). Subsequent studies have revealed a somewhat more complex picture, but confirmed frequent immigration from north-temperate areas (Gehrke and Linder, 2009), although showing that other temperate areas could also act as source. The recent and repeated immigration of species from the north is well illustrated in Arabis alpina (Koch et al., 2006; Assefa et al., 2007).

Similarly, the austral elements in the Cape flora (interpreted here to be part of the Austro-temperate Flora) have long attracted attention (Levyns, 1962, 1964), and recent analysis has shown that these are a substantial part of the flora (Galley and Linder, 2006), although the flora contains elements from most continents (Goldblatt, 1978). Remarkably few lineages have been recruited from South America into the Cape flora [but see Prionium (African) and Thurnia (South America) (Thurniaceae)], while the links to the more distant Australia are strong. The floristic exchange with Australia has been continuous throughout the Cenozoic. There is some indication that Paleogene exchanges were largely from Australia to the Cape flora [e.g., Proteaceae (Sauquet et al., 2009), Restionaceae (Galley and Linder, 2006) and Schoeneae (Verboom, 2006)], whereas exchange from the Cape to Australia seems to be more common in the Neogene (Bergh and Linder, 2009), involving, inter alia, genera like the Geraniaceae genus Pelargonium (Bakker et al., 1998) and the Campanulaceae genus Wahlenbergia (Prebble et al., 2011). Exchanges with tropical and north temperate areas are less common. They do, however, involve several noteworthy instances, such as Erica (McGuire and Kron, 2005) and Lobostemon, sister to the MediterraneanMacaronesia Echium (Boraginaceae) (Hilger and Böhle, 2000).

The linkages among the tropical floras have also long been known, despite their assignment to different floristic kingdoms (Takhtajan, 1986; Cox, 2001). In the Late Cretaceous and Paleogene, India was adjacent to East Africa and may have formed a bridge to south-east Asia (Conti et al., 2002; Rutschmann et al., 2004). Connections across the Atlantic Ocean have generally be regarded to be the result of long distance dispersal by wind or ocean current, and here, too, many disjunctions have been documented (Thorne, 1973; Renner, 2004). Several large South American clades have a small number of African species, for example Maschalocephalus dinklagei Gilg and K.Schum. (Rapateaceae), Rhipsalis cassytha Gaertn. (Cactaceae) and Pitcairnia feliciana (A.Chev.) Harms and Mildbr. (Bromeliaceae). These intercontinental exchanges are especially evident in the Lowland forest and Arid Floras. The complexity of these patterns is well illustrated by the remarkable disjunctions and complex biogeography of the mega-genus Euphorbia, with some 2000 species, many of which are succulent. Euphorbia probably originated in the Oligocene, but the bulk of its diversification was in the Neogene (Bruyns et al., 2011), and most subgenera and sections have species on most continents (Bruyns et al., 2011; Horn et al., 2012; Peirson et al., 2013; Riina et al., 2013), indicating much recent dispersal. Even though not included in any of our analyzed taxa, there are also tropical connections to Australia, best known of which is Adansonia (Malvaceae) (Baum et al., 1998).

These patterns are consistent with intercontinental dispersal being largely within biomes (Crisp et al., 2009). The habitat might also play a role, as is shown by the sister-species relationship between the tropical American Thurnia and the Cape Prionium (Thurniaceae): although the climatic regimes are quite different, both grow in permanent streams on highly oligotrophic soils. The large number of African flora elements which have their closest relatives in other floras in Africa (Table 1) show that much evolution in Africa is by adaptation rather than migration.

Our results suggest that diversification rates in the Austrotemperate Flora are higher than those in the tropical floras, and clades in the Austro-temperate Flora have more species than 
predicted by their age, growth form and source areas, than the tropical clades. The extreme case is in the core Ruschieae of the Aizoaceae, which has one of the highest diversification rates globally (Klak et al., 2004; Valente et al., 2014). However, generally the Cape flora (the most species rich part of the Austro-temperate Flora) does not have an exceptionally high diversification rate, compared to other areas were there have been floristic radiations (Linder, 2008). The only published comparison of diversification rates of groups inside and outside the Cape Floristic Region (Marloth, 1908; Goldblatt, 1978) has been for Protea, and here no higher diversification rate could be demonstrated in the Cape Floristic Region than in the Drakensberg and regions to the north (Valente et al., 2010). However, there is some indication that diversification rates may be higher in the Cape flora than in the Mediterranean (Valente et al., 2011). The latter compares two floras, while the former compared two regions within one flora, which might explain the result.

There are probably six African floras (Table 3), based on evidence from the distributions (also taxonomic composition), the affinities outside Africa, the differences in the diversification rates and the age of the floras. These six floras are more heuristic devices with which to evaluate the history of the African flora, rather than six distinct entities.

\section{AUSTRO-TEMPERATE FLORA}

The Austro-temperate Flora is centered in the south-western tip of Africa (Figure 8A), but is widespread in southern Africa with outliers in East Africa. It includes several elements: the "Cape flora" which radiated on the Cape mountains and intermontane valleys (Marloth, 1908; Goldblatt, 1978; Linder, 2003); the Drakensberg Alpine Center in the Drakensberg (Hilliard and Burtt, 1987; Carbutt and Edwards, 2006); the Namaqualand semidesert flora (Cowling et al., 1999; Snijman, 2013); and outliers further to the north in the Zimbabwean Chimanimani (Phipps and Goodier, 1962). Typical elements are Restionaceae (e.g., Elegia), Proteaceae (e.g., Protea, Mimetes), as well as taxa typical of the Drakensberg grasslands (e.g., Brownleea, Kniphofia).

The Cape flora has long been treated as highly distinct (Bolus, 1886; Marloth, 1908; Goldblatt, 1978; Linder, 2003), and it has even been recognized as one of the six floristic kingdoms (Good, 1974; Takhtajan, 1986). Indeed, there are a large number of clades centered in this region (the "Cape clades"), and endemism at both species and generic level to this region is extraordinarily high (Manning and Goldblatt, 2013). More striking is how few clades contributed substantially to this enormous species richness, and about half of the species can be attributed to just over 30 Cape clades (Linder, 2003). These clades have been well studied, indicating that most of the radiations of these clades date from the Miocene (Linder, 2005; Verboom et al., 2009), although in many cases the stem ages are much older. Many of these radiating clades are centered on, or even restricted to, the highly oligotrophic sandy soils derived from the sandstone bedrock of the Cape fold mountains, suggesting that they might be edaphic specialists predating the probably late Miocene origin of the unusual winter-rainfall climate (Dupont et al., 2011). However, the inception of the winter-rainfall climate may well have been the trigger for extensive speciation (Goldblatt, 1997).

There is much evidence that the Cape flora is not geographically sharply defined. There are outliers well beyond its main range in the south-western Cape (Weimarck, 1933, 1936, 1941), many of these are on quartzitic bedrock, for examples the sandstones of Pondoland (Van Wyk, 1989, 1990) and the quartzites of the Chimanimani mountains of Zimbabwe (Phipps and Goodier, 1962). Others are on well-leached soils at high altitudes in the Drakensberg (Killick, 1978; Carbutt et al., 2013). More striking, though, are the numerous genera that are as important a component in the tropic-montane grasslands of tropical Africa, as in the Cape, albeit with a much lower species richness. These genera include archetypal Cape clades such as Erica, Protea, Helichrysum, the orchid genera Disa and Satyrium and the grass genus Pentameris. In these clades the distribution can be described to be widespread in the cooler, more temperate, environments in Africa, but with a concentration of species richness in the south-western Cape. The opposite situation, where the greatest species richness is in the tropical African mountains and only a few species represent the clade in the south-western Cape, is much rarer. An example is the genus Kniphofia (Ramdhani et al., 2008). The floristic delimitation to the semi-arid south-western coast is equally poor. The vegetation is totally different: the Cape flora is a shrubland of highly branched, small-leaved, evergreen, sclerophyllous shrubs, while the dominant vegetation of Namaqualand is succulent. Floristically the two regions intergrade and intermix, and this lead to Jürgens (1997) suggesting that they should be combined. This was critically tested by Born et al. (2007) and implemented by Snijman (2013).

Possibly several cool and/or seasonal drought adapted clades differentiated during the middle Cenozoic in southern Africa. The Lesotho uplands were at a relatively high altitude throughout the Cenozoic (Partridge and Maud, 2000), providing a suitably moist and temperate habitat. Furthermore, the current rainfall gradient

Table 3 | Comparison of the attributes of the six postulated African floras.

\begin{tabular}{llllll}
\hline Flora & $\begin{array}{l}\text { Detected by geographical } \\
\text { analysis }\end{array}$ & $\begin{array}{l}\text { Geographically } \\
\text { distinct }\end{array}$ & $\begin{array}{l}\text { Extra-African } \\
\text { affinities }\end{array}$ & $\begin{array}{l}\text { Diversification } \\
\text { rate }\end{array}$ & $\begin{array}{l}\text { Oldest clades in } \\
\text { the flora }\end{array}$ \\
\hline Austro-temperate & Yes & Yes & Southern Hemisphere & Fast & Paleogene \\
Lowland forest & Yes & Yes & Tropical & Slow & Cretaceous \\
Tropic-montane & Yes & Yes & North Hemisphere and Asian & Slow & Miocene \\
Tropic-alpine & No & No & Northern Hemisphere & Slow & Late Miocene-Pliocene \\
Savanna & Yes & Yes & Tropical & Slow & Miocene \\
Arid & No & Possibly & Tropical & Slow & Paleogene
\end{tabular}




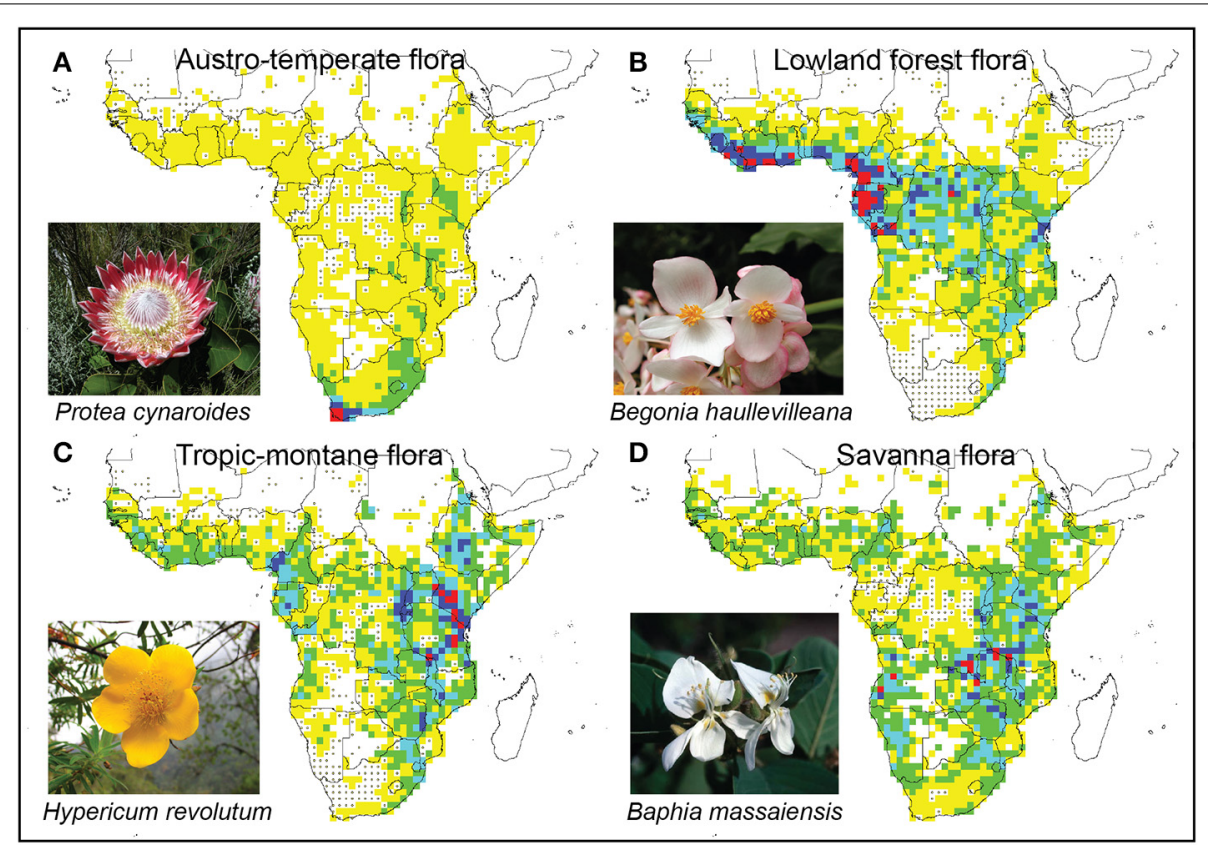

FIGURE 8 | Distribution patterns of four African floras, as defined by multivariate analyses (Figures 4, 5). Blank cells were excluded as they includes fewer than 5 genera, cells with dots contained no genera of the relevant flora. Color coding indicates the number of species assigned to that flora, with yellow cells with fewest species and red cells with most. Red cells can be seen as the centers of each eco-geographical radiation. (A) Austro-temperate Flora; (B) Lowland tropical Flora; (C) Tropic-montane Flora; (D) Savanna Flora. from east to west, with a relatively arid western side of the subcontinent, appears to have existed during the Eocene (Partridge and Maud, 2000) and probably persisted since then, and might have provided a suitable rainfall gradient over which clades could differentiate. These southern African temperate clades may have included the families Scrophulariaceae, Crassulaceae, Aizoaceae, large clades in Asteraceae, Fabaceae, and Iridaceae, and Poaceae subfamily Danthonioideae. Specialization to the oligotrophic soils of the Cape fold mountains, as these were exposed by erosion (Tinker et al., 2008a,b; Scharf et al., 2013), probably laid the foundation for the distinctive Cape floral elements such as Restionaceae and Proteaceae. Specialization to seasonal aridity on the West Coast subsequent to the climate changes induced by the increased activity and lower temperatures of the Benguela upwelling (Dupont et al., 2011), led to the Late Miocene radiation of clades in the succulent karoo (Klak et al., 2004; Verboom et al., 2009). The most recent specialization might be to the subalpine conditions along the summits of the Drakensberg, subsequent to the Pliocene uplift of ca. $900 \mathrm{~m}$ (Partridge and Maud, 2000), with erosional fragmentation leading to allopatric differentiation, for example in the daisy genus Macowania (Bentley et al., 2014). This scenario envisages a series of local radiations of a widespread southern African flora in response to new, extreme habitats, as these become available, and sees the iconic Cape flora as a part of this Austro-temperate Flora.

\section{LOWLAND FOREST FLORA}

The lowland forest genera form a geographically highly distinctive group, centered along the Atlantic coast from the Gambia to northern Angola, with a low density in the Congo basin, and with outliers in the Mombasa-Tanga coastal region of East Africa (Figure 8B). This includes genera such as Allanblackia, Garcinia, Begonia, Tricalysia, and Voacanga.

Lineages which belong to the Lowland forest Flora are the oldest lineages in our analysis, and date back into the Cretaceous, suggesting that African lowland forests are ancient. This corroborates other, global, analyzes based on palms (Couvreur et al., 2011) and Malpighiales (Wang et al., 2009) that forests of angiosperms are ancient. The current indications are not only that this is the oldest African flora, but also that it has persisted over the past $80 \mathrm{My}$.

Surprisingly little is known about the spatial evolution of this Flora in Africa. It might have been widespread in the African Paleogene (Plana, 2004), but there appears to be no direct evidence, except from around Mt Cameroun, where forest was reconstructed for the Eocene from pollen data (Utescher and Mosbrugger, 2007). These forests may have reached across Africa to the Indian ocean (Morley, 2000). This may well have been part of a pan-equatorial Paleogene hothouse forest, which became increasingly fragmented as the northern Indian Ocean was formed by the northward drift of India (Rutschmann et al., 2004). This continuous forest was subsequently fragmented in Africa by the Oligocene initiation of doming (Chorowicz, 2005), leading to the evolution of the East African Rift system with its complex system of cool uplands, dry rainshadows, and areas of high orographic rainfall (Sepulchre et al., 2006). Phylogeographical studies indicate that the eastern and western forests may have been fragmented and reconnected several times during the Miocene (Couvreur et al., 2008). During this period the East African forest patches may have been reduced in extent and were replaced by 
grassland and woodland (Morley, 2000). The contrasting patterns of high forest diversity in the Cameroun-Gabon areas, and low diversity across the Congo basin (Parmentier et al., 2007), have led to suggestions that in the Neogene the forest might at times have been reduced to a few refugia (Hamilton, 1982). Much of the herbaceous understory diversity in these forests is also concentrated in these putative refugia (Sosef, 1996; Küper et al., 2004). Off-shore sediments indeed indicate major fluctuations in rainforest along the west African coast during the last 150 kyrs, but also show that they were always present (Dupont et al., 2000).

The African lowland forests are, compared to those in South America and south-east Asia, species poor (Corlett and Primack, 2011). Parmentier et al. (2007) suggested that the low local diversity in the high-rainfall African forests may be due to a small African lowland, high rainfall forest species pool, which reflects a series of Neogene bottlenecks.

\section{TROPIC-MONTANE FLORA}

The Tropic-montane Flora is closely related to the Lowland forest Flora, but has its geographical center in the East African Arc, from Kitulo Plateau in the Southern Highlands of Tanzania, to Mt Elgon on the Uganda-Kenya border (Lovett, 1988, 1989, 1993a,b,c). The flora is widespread on all higher-lying land in Africa, from the Gambia to the Yemen, and south to Port Elizabeth (Figure 8C). Typical genera include upper forest margin genera like Hypericum, forest taxa such as Cussonia, Podocarpus and Impatiens, as well as grassland taxa such as Colpodium. The vegetation is a mosaic of evergreen, laurophyllous forests and grassland. Nearer the equator forest dominates with few grassland patches, at higher latitudes grassland dominates with a few isolated forest patches. The relative importance of these two vegetation types may have fluctuated extensively during the Pleistocene climate fluctuations (Meadows and Linder, 1993). At higher altitudes a scrubland with dense Erica-dominated vegetation can also occur (White, 1983).

Although this Tropic-montane Flora was recognized as a distinct unit by White (as "Afromontane," Chapman and White, 1970; White, 1978, 1981), regionalization studies based on species have failed to retrieve it (Linder et al., 2005, 2012b), possibly due to the high turnover in species composition between mountain blocks. The results here indicate that the flora can be recognized based on a distinct set of tropic-montane genera.

The few available dated clades indicate a Miocene age. This is consistent with the East African doming, but the number of clades investigated are too small to be confident of these results. Some African mountains predate the Miocene, suggesting that this flora could contain older elements. At the southern end it intergrades into the Austro-temperate Flora: although the Drakensberg system has generally been assigned to the "Afromontane" (White, 1983), the analysis here suggests that it is part of the Austrotemperate Flora. Many genera (e.g., Podocarpus) are widespread between the two systems, and consequently they have been combined as the "Afro-temperate flora" (Linder, 1990).

\section{TROPIC-ALPINE FLORA}

The Tropic-alpine Flora ["Afro-alpine" of Hedberg (1957) and White (1983)] is the youngest African flora. It forms a typical tropic-alpine vegetation, dominated by gaint rosette herbs, and adaptated to an aseasonal, diurnal freeze-thaw cycle (Smith and Cleef, 1988). The earliest clades are contemporanous with the Late Miocene age of the formation of these volcanic peaks (Wichura et al., 2010). No doubt there were earlier mountains in Africa, and particularly in Ethiopia extensive trappe lava flows in the Oligocene must have built substantial mountains (Chorowicz, 2005), but there is no evidence of alpine peaks before the Rift Valley volcanos.

Consistent with such a young flora, the immigration rate seems much higher than the local diversification rate (e.g., Carex, Gehrke and Linder, 2009), and the largest clades contain only a few species-possibly the largest local radiation is in Alchemilla (Gehrke et al., 2008).

\section{SAVANNA FLORA}

The Savanna Flora is rather poorly sampled in this study. The center of species richness is along the high ground forming the watershed between the Congo, Zambezi and Ruaha River systems, but it is widespread in the seasonally arid parts of the continent (Figure 8D). It includes both the Sudanian and Zambezian savannas recognized by White (1965). Included here are widespread savanna genera like Crotalaria and Kirkia. Also included here are some typical arid adapted taxa, such as Namibia. The most common vegetation is woodland, often with some grass in the understory and regular fire (White, 1983).

The Savanna Flora, with grasses as its key element, evolved in the Miocene, and in the Eocene no grass pollen was found in Africa (Utescher and Mosbrugger, 2007). From the Early Miocene onwards there are increasing proportions of grass pollen in the fossil record (Morley and Richards, 1993; Jacobs et al., 1999; Dupont et al., 2013; Feakins et al., 2013; Hoetzel et al., 2013), with indications of a dominance of $\mathrm{C}_{4}$ grasses dating only from the Late Miocene / Pliocene (Dupont et al., 2013; Feakins et al., 2013; Hoetzel et al., 2013). Many of the woody genera associated with African savannas also contain rainforest species (eg., Brachystegia, Isoberlinia, Acacia). Fossil records from West Africa indicate expansion and retraction of savannas after $6.3 \mathrm{Ma}$ (Morley, 2000). However, no critical evaluation of the evolutionary history of any of the typical clades of this flora is as yet available, and such an evaluation will no doubt be immensely valuable in giving an insight into the evolutionary history of not only this flora, but also of the Lowland forest Flora.

\section{ARID FLORA}

There are probably two Arid Floras in Africa. The one is associated with the south-west African coast and the Namib desert, and is at least partially a winter-rainfall arid flora, and is included here in the Austro-temperate Flora. The other is associated with a summer rainfall regime, and is found along the eastern part of the continent. This flora is what is often referred to as succulent thicket, thicket, or seasonally dry vegetation (White, 1983; Schrire et al., 2005a,b). It is not a grassland and, like forest, is not pyrophytic. It reaches into southern Africa, where it has received some attention (Cowling et al., 2005; Ramdhani et al., 2010; Potts et al., 2013). This flora is centered in the Somalia-Masai regional center of endemism White (1983). 
Seasonally arid habitats probably existed throughout the Cenozoic, even in the Paleogene hot-house earth, and some climatic reconstructions suggest that these were spatially as extensive as now (Huber and Goldner, 2012). This is consistent with the assembly of East African Eocene leaves which match those currently found in seasonally dry savannas (Jacobs and Herendeen, 2004). Our data are consistent with the Arid Flora dating to the Paleocene.

This flora, which is currently quite fragmented, would benefit from detailed exploration (Cowling et al., 2005; Schrire et al., 2005a). It is a relatively old flora, and radiations started in the Oligocene/Early Miocene in Euphorbia (Bruyns et al., 2011; Horn et al., 2012; Peirson et al., 2013) and Commiphora (Weeks and Simpson, 2007). There appears to be an interplay between dispersal among the arid habitats in Africa and repeated, local, radiations, illustrated well in the stem-succulent stapeliads (Bruyns et al., 2014) and the Rutaceae genus Thamnosma (Thiv et al., 2011). The Miocene evolution of savannas, and finally the Pliocene evolution of $\mathrm{C}_{4}$ grasslands and a massively increased fire frequency, may have transformed a large portion of the arid thicket vegetation into grassland.

\section{IMPACT OF $\mathrm{C}_{4}$ GRASSES, OR WHAT HAPPENED TO AFRICA'S BIODIVERSITY?}

The generally low species diversity of many of the African floras, compared to the other two major equator-straddling continents, South America and south-east Asia, is puzzling. There are several islands of high species richness in this generally speciespoor continent: the Cape flora as the by far most species-rich mediterranean-type ecosystem, the adjacent succulent karoo, as the most species rich semi-arid flora (both part of the Austrotemperate Flora), and the lowland forests between Gabon and $\mathrm{Mt}$ Cameroun, which are on a par with rainforests in South America and south-east Asia. This suggests that some event in the past erased much of the African diversity, and did it in clearly delimited biomes. No doubt climatic deterioration, as suggested by many researchers (e.g., Dransfield, 1988; Morley and Richards, 1993) might have been a factor, but global climatic deterioration should also have played a role in the other continents, and should have impacted all African floras.

The three species-rich African areas share the historical and current absence of $\mathrm{C}_{4}$ grasses. Grasses start spreading in the Miocene, with several reports of increasing importance of grass pollen from East Africa (Jacobs et al., 1999; Feakins et al., 2013) and southern Africa (Dupont et al., 2013; Hoetzel et al., 2013). In both East African and southern Africa this early grassland appears to have been $\mathrm{C}_{3}$ dominated: the signature of $\mathrm{C}_{4}$ dominance, as inferred from the stable isotope composition of plant waxes retrieved from a deep sea drilling core off Namibia, dates only from the Late Miocene/Pliocene or even during the Pleistocene (Hoetzel et al., 2013). This leads to the suggestion that $\mathrm{C}_{4}$ grasses may have replaced $\mathrm{C}_{3}$ grasses rather than woody vegetation (Feakins et al., 2013). In southern Africa, this increase in dominance of $\mathrm{C}_{4}$ grasses coincides with a massive increase in charcoal (Hoetzel et al., 2013), suggesting that with $\mathrm{C}_{4}$ grasses there is an increase in fire frequency. The link between the dominance of $\mathrm{C}_{4}$ grasses and fires is frequently made (Bond et al.,
2003, 2005; Beerling and Osborne, 2006). A similar coincidence of increased grass pollen and charcoal is also reported from the Middle Miocene of the Gulf of Guinea, but without an indication whether this was $\mathrm{C}_{3}$ or $\mathrm{C}_{4}$ grassland (Morley and Richards, 1993). Such a massive increase in fire frequency in a modern system would be associated with extensive extinction, and there is no reason to believe that it was any other in the Late Miocene. Not only does Africa have more extensive $\mathrm{C}_{4}$ savannas than all other continents, but their extent was much larger during the glacial maxima (Scott, 2002), but not in the winter rainfall parts of southern Africa. This suggest that $\mathrm{C}_{4}$ grasslands may have driven a massive orgy of extinction during the Late Miocene and Pliocene. The fire refuge areas (Cape fynbos, succulent karoo and the GabonCamerounian rainforests) are relicts of what may once have been a much more species rich flora. All these areas do contain grasses, but these are $\mathrm{C}_{3}$ grasses, and they occur at a much lower density, so that they do not drive annual fires as is the case in savanna systems. This hypothesis predicts that regions that have been $\mathrm{C}_{4}$ grassland since the end Miocene might have accumulated, and those never invaded by $\mathrm{C}_{4}$ grassland retained, rich floras. However, areas that are on the dynamic interface between floras (savanna-rainforest, or savanna-arid) might be impoverished.

Although fire requires a dry season of several months, the dry season itself does not result in fire. This is evident both from the semi-arid south west African coast, with its succulent vegetation, and to the north very sparse desert flora. Here an increase in desert indicator pollen in the Plio-Pleistocene record is matched by a decrease in the charcoal in the deposits (Hoetzel et al., 2013), vividly illustrating the requirement of a minimum of rain for fire. Both fynbos in the Cape flora and the seasonally dry thicket in north-east Africa have sufficient growth to support fire, and a dry season, but lack $\mathrm{C}_{4}$ grasses. The result is fire on a decadal scale in the fynbos, or not at all in the seasonally dry thicket. This illustrates the importance of $\mathrm{C}_{4}$ grasses as biotic modifiers (Linder et al., 2012a) in introducing fire at an annual scale and transforming the vegetation to a savanna.

\section{SUMMARY}

The current plant diversity in Africa can be interpreted as the result of the sequential adding of new floras. The continent entered the Cenozoic with the Lowland forest Flora. During the Paleocene the Arid Flora and the Austro-temperate Floras were added. The doming and volcanism of the Neogene resulted in the adding of the Tropic-montane and a Tropic-alpine Floras. The Savanna Flora may have been the result of a biotic event-the evolution and spread of grassland. However, what is not clear is whether there were other floras in the past, which are now extinct or so reduced as to be difficult to detect. The patterns of species accumulation seem to differ among the floras, and the Austrotemperate Flora may be accumulating species more rapidly than the other floras. There could be a relationship between standing diversity and exposure to invasion by grassland, particularly by $\mathrm{C}_{4}$ grassland with its associated high fire frequency.

We know very little about the processes linked to diversification (speciation and extinction) in these floras. Africa, with its highly diverse landscape and intermingled floras, offers an excellent opportunity to disentangle the effects of environmental 
variables such as topographical complexity, climatic stability, and climatic extremes, from biotic variables such as fire frequency and herbivory. We are right at the beginning of starting to disentangle the processes that have led to the diversity of species and biomes.

\section{ACKNOWLEDGMENTS}

The University of Zurich is thanked for funding, Jens Muttke for making the Bonn dataset available, and Yanis BouchenakKhelladi for advice on R, Tony Verboom for dates of numerous southern African clades, Yanis Bouchenak-Khelladi, Renske Onstein, and Tony Verboom for insightful comments on an earlier draft of the manuscript. This paper would not have happened if William Bond had not nagged me about fires and grasses.

\section{SUPPLEMENTARY MATERIAL}

The Supplementary Material for this article can be found online at: http://www.frontiersin.org/journal/10.3389/fevo.2014.00038/ abstract

\section{REFERENCES}

Assefa, A., Ehrich, D., Taberlet, P., Nemomissa, S., and Brochmann, C. (2007). Pleistocene colonization of afro-alpine 'sky islands' by the arctic-alpine Arabis alpina. Heredity (Edinb). 99, 133-142. doi: 10.1038/sj.hdy.6800974

Bakker, F. T., Hellbrügge, D., Culham, A., and Gibby, M. (1998). Phylogenetic relationships within Pelargonium sect. Peristera (Geraniaceae), inferred from nrDNA and cpDNA sequence comparisons. Plant Syst. Evol. 211, 273-287. doi: 10.1007/BF00985364

Baum, D. A., Small, R. L., and Wendel, J. F. (1998). Biogeography and floral evolution of baobabs (Adansonia, Bombaceae) as inferred from multiple data sets. Syst. Biol. 47, 181-207. doi: 10.1080/106351598260879

Beerling, D. J., and Osborne, C. P. (2006). The origin of the savanna biome. Glob. Chang. Biol. 12, 2023-2031. doi: 10.1111/j.1365-2486.2006.01239.x

Bellstedt, D. U., Galley, C., Pirie, M. D., and Linder, H. P. (2012). The migration of the palaeotropical arid flora: Zygophylloideae as an example. Syst. Bot. 37, 951-959. doi: 10.1600/036364412x656608

Bentley, J., Verboom, G. A., and Bergh, N. G. (2014). Erosive processes after tectonic uplift stimulate vicariant and adaptive speciation: evolution in an Afrotemperate-endemic paper daisy genus. BMC Evol. Biol. 14:27. doi: 10.1186/1471-2148-14-27

Bergh, N. G., and Linder, H. P. (2009). Cape diversification and repeated outof-southern-Africa dispersal in paper daisies (Asteraceae-Gnaphalieae). Mol. Phylogenet. Evol. 51, 5-18. doi: 10.1016/j.ympev.2008.09.001

Bolus, H. (1886). Sketch of the Flora of South Africa. Cape Town: Richards and Sons.

Bond, W. J., Midgley, G. F., and Woodward, F. I. (2003). The importance of low atmospheric $\mathrm{CO} 2$ and fire in promoting the spread of grasslands and savannas. Glob. Chang. Biol. 9, 973-982. doi: 10.1046/j.1365-2486.2003.00577.x

Bond, W. J., Woodward, F. I., and Midgley, G. F. (2005). The global distribution of ecosystems in a world without fire. New Phytol. 165, 525-537. doi: 10.1111/j.1469-8137.2004.01252.x

Born, J., Linder, H. P., and Desmet, P. (2007). The greater cape floristic region. J. Biogeogr. 34, 147-162. doi: 10.1111/j.1365-2699.2006.01595.x

Bruyns, P. V., Klak, C., and Hanáček, P. (2014). Evolution of the stapeliads (Apocynaceae-Asclepiadoideae)—repeated major radiation across Africa in an Old World group. Mol. Phylogenet. Evol. 77, 251-263. doi: 10.1016/j.ympev. 2014.03.022

Bruyns, P. V., Klak, C., and Hanek, P. (2011). Age and diversity in Old World succulent species of Euphorbia (Euphorbiaceae). Taxon 60, 1717-1733.

Carbutt, C., and Edwards, T. J. (2006). The endemic and near-endemic angiosperms of the Drakensberg Alpine Centre. S. Afr. J. Bot. 72, 105-132. doi: 10.1016/j.sajb.2005.06.001

Carbutt, C., Edwards, T. J., Fynn, R. W. S., and Beckett, R. P. (2013). Evidence for temperature limitation of nitrogen mineralisation in the Drakensberg Alpine Centre. S. Afr. J. Bot. 88, 447-454. doi: 10.1016/j.sajb.2013.09.001

Chapman, J. D., and White, F. (1970). The Evergreen Forests of Malawi. Oxford: Commonwealth Forestry Institute.
Chorowicz, J. (2005). The East African rift system. J. Afr. Earth Sci. 43, 379-410. doi: 10.1016/j.jafrearsci.2005.07.019

Conti, E., Eriksson, T., Schonenberger, J., Sytsma, K. J., and Baum, D. A. (2002). Early tertiary out-of-India dispersal of Crypteroniaceae: evidence from phylogeny and molecular dating. Evolution 56, 1931-1942. doi: 10.1111/j.00143820.2002.tb00119.x

Corlett, R. T., and Primack, R. B. (2011). Tropical Rain Forests: An Ecological and Biogeographical Comparison. Chichester: Wiley-Blackwell.

Couvreur, T. L. P., Chatrou, L. W., Sosef, M. S. M., and Richardson, J. E. (2008). Molecular phylogenetics reveal multiple tertiary vicariance origins of the African rain forest trees. BMC Biol. 6:54. doi: 10.1186/1741-70 07-6-54

Couvreur, T. L. P., Forest, F., and Baker, W. J. (2011). Origin and global diversification patterns of tropical rain forests: inferences from a complete genus-level phylogeny of palms. BMC Biol. 9:44. doi: 44 10.1186/1741-7007-9-44

Cowling, R. M., Esler, K. J., and Rundel, P. W. (1999). Namaqualand, South Africaan overview of a unique winter-rainfall desert ecosystem. Plant Ecol. 142, 3-21. doi: 10.1023/A:1009831308074

Cowling, R. M., Procheş, S., and Vlok, J. H. J. (2005). On the origin of the southern African subtropical thicket vegetation. S. Afr. J. Bot. 71, 1-23.

Cox, C. B. (2001). The biogeographic regions reconsidered. J. Biogeogr. 28, 511-523. doi: 10.1046/j.1365-2699.2001.00566.x

Crisp, M. D., Arroyo, M. T. K., Cook, L. G., Gandolfo, M. A., Jordan, G. J., McGlone, M. S., et al. (2009). Phylogenetic biome conservatism on a global scale. Nature 458, 754-756. doi: 10.1038/nature07764

Davis, C. C., Bell, C. D., Fritsch, P. W., and Mathews, S. (2002). Phylogeny of Acridocarpus-Brachylophon (Malpighiaceae): implications for tertiary tropical floras and Afroasian biogeography. Evolution 56, 2395-2405. doi: 10.1111/j.0014-3820.2002.tb00165.x

Davis, S. D. (1995). "Regional overview: South East Asia (Malesia)," in Centres of Plant Diversity. A Guide and Strategy for Their Conservation, eds S. D. Davis, V. H. Heywood, and A. C. Hamilton (Cambridge: IUCN), 229-432.

Denys, E. (1980). A tentatative phytogeographical division of tropical Africa based on a mathematical analysis of distribution maps. Bull. Jard. Bot. Natl. Belg. 50, 465-504. doi: 10.2307/3667842

De Winter, B. (1966). Remarks on the distribution of some desert plants in Africa. Palaeoecol. Afr. 1, 188-189.

De Winter, B. (1971). Floristic relationships between the northern and southern arid areas in Africa. Mitt. Bot. Staatssamml. Münch. 10, 424-437.

Dransfield, J. (1988). "The palms of Africa and their relationships," in Systematic Studies in African Botany, eds P. Goldblatt and P. P. Lowry (St Louis: Missouri Botanical Garden), 95-103.

Dupont, L. M., Jahns, S., Marret, F., and Ning, S. (2000). Vegetation change in equatorial West Africa: time-slices for the last $150 \mathrm{ka}$. Palaeogeogr. Palaeoclimatol. Palaeoecol. 155, 95-122. doi: 10.1016/S0031-0182(99)00095-4

Dupont, L. M., Linder, H. P., Rommerskirchen, F., and Schefuss, E. (2011). Climatedriven rampant speciation of the Cape flora. J. Biogeogr. 38, 1059-1068. doi: 10.1111/j.1365-2699.2011.02476.x

Dupont, L. M., Rommerskirchen, F., Mollenhauer, G., and Schefuss, E. (2013). Miocene to Pliocene changes in South African hydrology and vegetation in relation to the expansion of C-4 plants. Earth Planet. Sci. Lett. 375, 408-417. doi: 10.1016/j.epsl.2013.06.005

Faden, R. B. (1974). "East African coastal-West African rain forest disjunctions," in East African Vegetation, eds E. M. Lind and M. E. S. Morrison (London: Longman), 202-203.

Feakins, S. J., Levin, N. E., Liddy, H. M., Sieracki, A., Eglinton, T. I., and Bonnefille, R. (2013). Northeast African vegetation change over 12 m.y. Geology 41, 295-298. doi: 10.1130/g33845.1

Galley, C., Bytebier, B., Bellstedt, D. U., and Linder, H. P. (2007). The Cape element in the Afrotemperate flora: from Cape to Cairo? Proc. R. Soc. Lond. B 274, 535-543. doi: 10.1098/rspb.2006.0046

Galley, C., and Linder, H. P. (2006). Geographical affinities of the Cape flora, South Africa. J. Biogeogr. 33, 236-250. doi: 10.1111/j.1365-2699.2005.0 1376.x

Gehrke, B., Bräuchler, C., Romoleroux, K., Lundberg, M., Heubl, G., and Eriksson, T. (2008). Molecular phylogenetics of Alchemilla, Aphanes and Lachemilla (Rosaceae) inferred from plastid and nuclear intron and spacer DNA sequences, with comments on generic classification. Mol. Phylogenet. Evol. 47, 1030-1044. doi: 10.1016/j.ympev.2008.03.004 
Gehrke, B., and Linder, H. P. (2009). The scramble for Africa: pan-temperate elements on the African high mountains. Proc. R. Soc. B-Biol. Sci. 276, 2657-2665. doi: 10.1098/rspb.2009.0334

Goldblatt, P. (1978). An analysis of the flora of southern Africa: its characteristics, relationships, and origins. Ann. Mo. Bot. Gard. 65, 369-436. doi: $10.2307 / 2398858$

Goldblatt, P. (1997). Floristic diversity in the Cape Flora of South Africa. Biodivers. Conserv. 6, 359-377. doi: 10.1023/A:1018360607299

Good, R. (1974). The Geography of the Flowering Plants, 4th Edn. London: Longman.

Grimshaw, J. M. (2001). What do we really know about the Afromontane archipelago. Syst. Geogr. Plants 71, 949-957. doi: 10.2307/3668730

Griswold, C. E. (1991). Cladistic biogeography of Afromontane spiders. Aust. Syst. Bot. 4, 73-89. doi: 10.1071/SB9910073

Hamilton, A. C. (1982). Environmental History of East Africa. London: Academic Press.

Hedberg, O. (1957). Afro-alpine vascular plants. A taxonomic revision. Symb. Bot. Ups. 15, 1-411.

Hedberg, O. (1965). Afroalpine flora elements. Webbia 19, 519-529.

Hilger, H. H., and Böhle, U.-R. (2000). Pontechium: a new genus distinct from Echium and Lobostemon (Boraginaceae). Taxon 49, 737-746. doi: $10.2307 / 1223974$

Hilliard, O. M., and Burtt, B. L. (1987). The Botany of the Southern Natal Drakensberg. Cape Town: National Botanic Gardens.

Hoetzel, S., Dupont, L., Schefuss, E., Rommerskirchen, F., and Wefer, G. (2013). The role of fire in Miocene to Pliocene C-4 grassland and ecosystem evolution. Nat. Geosci. 6, 1027-1030. doi: 10.1038/ngeo1984

Holstein, N., and Renner, S. S. (2011). A dated phylogeny and collection records reveal repeated biome shifts in the African genus Coccinia (Cucurbitaceae). BMC Evol. Biol. 11:28. doi: 10.1186/1471-2148-11-28

Horn, J. W., Van Ee, B. W., Morawetz, J. J., Riina, R., Steinmann, V. W., Berry, P. E., et al. (2012). Phylogenetics and the evolution of major structural characters in the giant genus Euphorbia L. (Euphorbiaceae). Mol. Phylogenet. Evol. 63, 305-326. doi: 10.1016/j.ympev.2011.12.022

Huber, M., and Goldner, A. (2012). Eocene monsoons. J. Asian Earth Sci. 44, 3-23. doi: 10.1016/j.jseaes.2011.09.014

Jacobs, B. F., and Herendeen, P. S. (2004). Eocene dry climate and woodland vegetation in tropical Africa reconstructed from fossil leaves from northern Tanzania. Palaeogeogr. Palaeoclimatol. Palaeoecol. 213, 115-123. doi: 10.1016/j.palaeo.2004.07.007

Jacobs, B. F., Kingston, J. D., and Jacobs, L. L. (1999). The origin of grass-dominated ecosystems. Ann. Mo. Bot. Gard. 86, 590-643. doi: 10.2307/2666186

Jürgens, N. (1997). Floristic biodiversity and history of African arid regions. Biodivers. Conserv. 6, 495-514. doi: 10.1023/A:1018325026863

Kier, G., Kreft, H., Lee, T. M., Jetz, W., Ibisch, P. L., Nowicki, C., et al. (2009). A global assessment of endemism and species richness across island and mainland regions. Proc. Natl. Acad. Sci. U.S.A. 106, 9322-9327. doi: 10.1073/pnas.0810306106

Killick, D. J. B. (1978). “The Afro-alpine region," in Biogeography and Ecology of Southern Africa, ed M. J. A. Werger (The Hague: Junk), 515-560. doi: 10.1007/978-94-009-9951-0_12

Klak, C., Reeves, G., and Hedderson, T. A. (2004). Unmatched tempo of evolution in Southern African semi-desert ice plants. Nature 427, 63-65. doi: 10.1038 /nature 02243

Klopper, R. R., Gautier, L., Chatelain, C., Smith, G. F., and Spichiger, R. (2007). Floristics of the angiosperm flora of sub-Saharan Africa: an analysis of the African plant checklist and database. Taxon 56, 201-208.

Klopper, R. R., Gautier, L., Smith, G. F., Spichiger, R., and Chatelain, C. (2006). Inventory of the African flora: a world first for the forgotten continent. S. Afr. J. Sci. 102, 185-186.

Koch, M. A., Kiefer, C., Ehrich, D., Vogel, J., Brochmann, C., and Mummenhoff, K. (2006). Three times out of Asia Minor: the phylogeography of Arabis alpina L. (Brassicaceae). Mol. Ecol. 15, 825-839. doi: 10.1111/j.1365-294X.2005.02848.x

Kreft, H., and Jetz, W. (2010). A framework for delineating biogeographical regions based on species distributions. J. Biogeogr. 37, 2029-2053. doi: 10.1111/j.13652699.2010.02375.x

Küper, W., Sommer, H., Lovett, J. C., Mutke, J., Linder, H. P., Beentje, H. J., et al. (2004). Africa's hotspots of biodiversity redefined. Ann. Mo. Bot. Gard. 91, $525-535$.
Küper, W., Sommer, J. H., Lovett, J. C., and Barthlott, W. (2006). Deficiency in African plant distribution data-missing pieces of the puzzle. Bot. J. Linn. Soc. 150, 355-368. doi: 10.1111/j.1095-8339.2006.00494.x

Levyns, M. R. (1962). Possible antarctic elements in the South African flora. S. Afr. J. Sci. 58, 237-241.

Levyns, M. R. (1964). Presidential address, migrations and origin of the Cape flora. Tran. R. Soc. S. Afr. 37, 85-107. doi: 10.1080/00359196409519059

Linder, H. P. (1990). On the relationship between the vegetation and floras of the Afromontane and the Cape regions of Africa. Mitt. Inst. Allg. Bot. Hamburg 23b, 777-790.

Linder, H. P. (1998). "Historical interpretation of the African phytochoria," in Chorology, Taxonomy and Ecology of the African and Madagascan Floras, eds C. R. Huxley, J. M. Lock, and D. F. Cutler (Kew: Royal Botanical Gardens), 67-86.

Linder, H. P. (2001). Plant diversity and endemism in sub-Saharan tropical Africa. J. Biogeogr. 28, 169-182. doi: 10.1046/j.1365-2699.2001.00527.x

Linder, H. P. (2003). The radiation of the Cape flora, southern Africa. Biol. Rev. 78, 597-638. doi: 10.1017/S1464793103006171

Linder, H. P. (2005). The evolution of diversity: the Cape flora. Trends Plant Sci. 10, 536-541. doi: 10.1016/j.tplants.2005.09.006

Linder, H. P. (2008). Plant species radiations: where, when, why? Philos. Trans. $R$. Soc. 363, 3097-3105. doi: 10.1098/rstb.2008.0075

Linder, H. P., Bykova, O., Dyke, J., Etienne, R. S., Hickler, T., Kühn, I., et al. (2012a). Biotic modifiers, environmental modulation and species distribution models. J. Biogeogr. 39, 2179-2190. doi: 10.1111/j.1365-2699.2012.02705.x

Linder, H. P., De Klerk, H. M., Born, J., Burgess, N. D., Fjeldså, J., and Rahbek, C. (2012b). The partitioning of Africa: statistically defined biogeographical regions in sub-Saharan Africa. J. Biogeogr. 39, 1189-1205. doi: 10.1111/j.13652699.2012.02728.x

Linder, H. P., Lovett, J. C., Mutke, J., Barthlott, W., Jürgens, N., Rebelo, A. G., et al. (2005). A numerical re-evaluation of the sub-Saharan phytochoria of mainland Africa. Biol. Skr. 55, 229-252.

Lovett, J. C. (1988). "Endemism and affinities of the Tanzanian montane forest flora," in Systematic studies in African botany, eds P. Goldblatt and P. P. Lowry (St Louis: Missouri Botanical Garden), 591-598.

Lovett, J. C. (1989). "The botanical importance of the East Usambara forests in relation to other forests in Tanzania," in Forest Conservation in the East Usambara Mountains, Tanzania, eds A. C. Hamilton and R. Bensted-Smith (Gland: IUCN), 207-212.

Lovett, J. C. (1993a). "Climatic history and forest distribution in eastern Africa," in Biogeography and Ecology of the Rain Forests of Eastern Africa, eds J. C. Lovett and S. K. Wasser (Cambridge: Cambridge University Press), 23-29.

Lovett, J. C. (1993b). "Eastern Arc moist forest flora," in Biogeography and Ecology of the Rain Forests of Eastern Africa, eds J. C. Lovett and S. K. Wasser (Cambridge: Cambridge University Press), 33-55.

Lovett, J. (1993c). Temperate and tropical floras in the mountains of Eastern Tanzania. Opera Bot. 121, 217-227.

Maechler, M., Rousseeuw, P., Struyf, A., Hubert, M., and Hornik, K. (2011). cluster: Cluster Analysis Basics and Extensions. R package version 1.14.1. Available online at: http://cran.r-project.org/web/packages/cluster/index.html

Manning, J., and Goldblatt, P. (eds.). (2013). Plants of the Greater Cape Floristic Region. 1. The core Cape Flora. Pretoria: South African National Biodiversity Institute.

Marloth, R. (1908). "Das Kapland, insonderheit das Reich der Kapflora, das Waldgebiet und die Karroo, pflanzengeographisch dargestelt, " in Wissenschaffliche Ergebnisse der deutschen Tiefsee-Expedition auf dem Dampfer "Valdivia" 1898-1899, ed C. Chun (Jena: Gustav Fischer), 1-427.

McGuire, A. F., and Kron, K. A. (2005). Phylogenetic relationships of European and African Ericas. Int. J. Plant Sci. 166, 311-318. doi: 10.1086/427478

Meadows, M. E., and Linder, H. P. (1993). A palaeoecological perspective on the origin of Afromontane grasslands. J. Biogeogr. 20, 345-355. doi: $10.2307 / 2845584$

Misiewicz, T. M., and Zerega, N. C. (2012). Phylogeny, biogeography and characters evolution of Dorstenia (Moraceae). Edinb. J. Bot. 69, 413-440. doi: $10.1017 /$ S096042861200025X

Morley, R. J. (2000). Origin and Evolution of Tropical Rain Forests. Chichester: Wiley. Morley, R. J., and Richards, K. (1993). Gramineae cuticle: a key indicator of Late Cenozoic climatic change in the Niger Delta. Rev. Palaeobot. Palynol. 77, 119-127. doi: 10.1016/0034-6667(93)90060-8 
Mutke, J., and Barthlott, W. (2005). Patterns of vascular plant diversity at continental to global scales. Biol. Skr. 55, 521-531.

Oksanen, J., Blanchet, F. G., Kindt, R., Legendre, P., Minchin, P. R., O'Hara, R. B., et al., (2012). vegan: Community Ecology Package. 2.0-5 Edn. Available online at: http://cran.r-project.org/web/packages/vegan/index.html

Parmentier, I., Malhi, Y., Senterre, B., Whittaker, R. J., Alonso, A., Balinga, M. P. B., et al. (2007). The odd man out? Might climate explain the lower tree alphadiversity of African rain forests relative to Amazonian rain forests? J. Ecol. 95, 1058-1071. doi: 10.1111/j.1365-2745.2007.01273.x

Partridge, T. C., and Maud, R. R. (2000). "Macro-scale geomorphic evolution of southern Africa," in The Cenozoic of southern Africa, eds T. C. Partridge and R. R. Maud (Oxford: Oxford University Press), 3-18.

Peirson, J. A., Bruyns, P. V., Riina, R., Morawetz, J. J., and Berry, P. E. (2013). A molecular phylogeny and classification of the largely succulent and mainly African Euphorbia subg. Athymalus (Euphorbiaceae). Taxon 62, 1178-1199. doi: $10.12705 / 626.12$

Phipps, J. B., and Goodier, R. (1962). A preliminary account of the plant ecology of the Chimanimani Mountains. J. Ecol. 50, 291-391. doi: 10.2307/2257446

Plana, V. (2004). Mechanisms and tempo of evolution in the African GuineoCongolian rainforest. Philos. Trans. R. Soc. Lond. B 359, 1585-1594. doi: 10.1098/rstb.2004.1535

Potts, A. J., Hedderson, T. A., Franklin, J., and Cowling, R. M. (2013). The Last Glacial Maximum distribution of South African subtropical thicket inferred from community distribution modelling. J. Biogeogr. 40, 310-322. doi: 10.1111/j.1365-2699.2012.02788.x

Prebble, J. M., Cupido, C. N., Meudt, H. M., and Garnock-Jones, P. J. (2011). First phylogenetic and biogeographical study of the southern bluebells (Wahlenbergia, Campanulaceae). Mol. Phylogenet. Evol. 59, 636-648. doi: 10.1016/j.ympev.2011.03.013

Ramdhani, S., Barker, N. P., and Baijnath, H. (2008). Exploring the Afromontane centre of endemism: Kniphofia Moench (Asphodelaceae) as a floristic indicator. J. Biogeogr. 35, 2258-2273. doi: 10.1111/j.1365-2699.2008. 01982.x

Ramdhani, S., Cowling, R. M., and Barker, N. P. (2010). Phylogeography of Schotia (Fabaceae): recent evolutionary processes in an ancient thicket biome lineage. Int. J. Plant Sci. 171, 626-640. doi: 10.1086/653133

R Development Core Team (2012). R: A language and environment for statistical computing. 2.15.2 GUI 1.53 Edn. Vienna: R Foundation for Statistical Computing.

Renner, S. S. (2004). Plant dispersal across the tropical Atlantic by wind and sea currents. Int. J. Plant Sci. (Suppl.) 165, S23-S33. doi: 10.1086/383334

Riina, R., Peirson, J. A., Geltman, D. V., Molero, J., Frajman, B., Pahlevani, A., et al. (2013). A worldwide molecular phylogeny and classification of the leafy spurges, Euphorbia subgenus Esula (Euphorbiaceae). Taxon 62, 316-342. doi: $10.12705 / 622.3$

Rutschmann, F., Eriksson, T., Schönenberger, J., and Conti, E. (2004). Did Crypteroniaceae really disperse out of India? Molecular dating evidence from rbcL, ndhF, and rpl16 intron sequences. Int. J. Plant Sci. Suppl. 165, S69-S83. doi: $10.1086 / 383335$

Sanmartin, I., Lisa Anderson, C., Alarcon, M., Ronquist, F., and Jose Aldasoro, J. (2010). Bayesian island biogeography in a continental setting: the Rand Flora case. Biol. Lett. 6, 703-707. doi: 10.1098/rsbl.2010.0095

Sauquet, H., Weston, P. H., Barker, N. P., Anderson, C. L., Cantrill, D. J., and Savolainen, V. (2009). Using fossils and molecular data to reveal the origins of the Cape proteas (subfamily Proteoideae). Mol. Phylogenet. Evol. 51, 31-43. doi: 10.1016/j.ympev.2008.12.013

Scharf, T. E., Codilean, A. T., De Wit, M., Jansen, J. D., and Kubik, P. W. (2013). Strong rocks sustain ancient postorogenic topography in southern Africa. Geology 41, 331-334. doi: 10.1130/G33806.1

Schrire, B. D., Lavin, M., and Lewis, G. P. (2005a). Global distribution patterns of the Leguminosae: insights from recent phylogenies. Biol. Skr. 55, 375-422.

Schrire, B. D., Lewis, G. P., and Lavin, M. (2005b). "Biogeography of the Leguminosae," in Legumes of the World, eds G. P. Lewis, B. D. Schrire, B. Mackinder and J. M. Lock (Kew: The Royal Botanic Gardens), $21-54$.

Scott, L. (2002). Grassland development under glacial and interglacial conditions in southern Africa: review of pollen, phytolith and isotope evidence. Palaeogeogr. Palaeoclimatol. Palaeoecol. 177, 47-57. doi: 10.1016/S0031-0182(01)0 0351-0
Sepulchre, P., Ramstein, G., Fluteau, F., Schuster, M., Tiercelin, J. J., and Brunet, M. (2006). Tectonic uplift and Eastern Africa aridification. Science 313, 1419-1423. doi: $10.1126 /$ science. 1129158

Smith, J. M. B., and Cleef, A. M. (1988). Composition and origins of the world's tropicalpine floras. J. Biogeogr. 15, 631-645. doi: 10.2307/2845441

Snijman, D. A. (ed.). (2013). Plants of the Great Cape Floristic Region. 2: The Extra Cape Flora. Pretoria: South African National Biodiversity Institute.

Sosef, M. S. M. (1996). "Begonias and African rain forest refuges: general aspects and recent progress," in The Biodiversity of African Plants, eds L. J. G. Van Der Maesen, X. M. Van Der Burgt, and J. M. Van Medenbach De Rooy. (Dordrecht: Kluwer), 602-611.

Takhtajan, A. (1986). Floristic Regions of the World. Berkeley: University of California Press.

Thiv, M., Van Der Niet, T., Rutschmann, F., Thulin, M., Brune, T., and Linder, H. P. (2011). Old-New World and trans-African disjunctions of Thamnosma (Rutaceae): intercontinental long-distance dispersal and local differentiation in the succulent biome. Am. J. Bot. 98, 76-87. doi: 10.3732/ajb. 1000339

Thorne, R. F. (1973). "Floristic relationships between tropical Africa and tropical America," in Tropical Forest Ecosystems in Africa and South America: A Comparative Review, eds B. J. Meggers, A. S. Ayensu, and W. D. Duckworth (Washington: Smithsonian Institution Press), 27-47.

Tinker, J., De Wit, M., and Brown, R. (2008a). Linking source and sink: evaluating the balance between onshore erosion and offshore sediment accumulation since Gondwana break-up, South Africa. Tectonophysics 455, 94-103. doi: 10.1016/j.tecto.2007.11.040

Tinker, J., De Wit, M., and Brown, R. (2008b). Mesozoic exhumation of the southern Cape, South Africa, quantified using apatite fission track thermochronology. Tectonophysics 455, 77-93. doi: 10.1016/j.tecto.2007.10.009

Utescher, T., and Mosbrugger, V. (2007). Eocene vegetation patterns reconstructed from plant diversity - A global perspective. Palaeogeogr. Palaeoclimatol. Palaeoecol. 247, 243-271. doi: 10.1016/j.palaeo.2006.10.022

Valente, L. M., Britton, A. W., Powell, M. P., Papadopulos, A. S. T., Burgoyne, P. M., and Savolainen, V. (2014). Correlates of hyperdiversity in southern African ice plants (Aizoaceae). Bot. J. Linn. Soc. 174, 110-129. doi: 10.1111/boj. 12117

Valente, L. M., Reeves, G., Schnitzler, J., Mason, I. P., Fay, M. F., Rebelo, T. G., et al. (2010). Diversification of the African genus Protea (Proteaceae) in the Cape biodiversity hotspot and beyond: equal rates in different biomes. Evolution 64, 745-760. doi: 10.1111/j.1558-5646.2009.00856.x

Valente, L. M., Savolainen, V., Manning, J. C., Goldblatt, P., and Vargas, P. (2011). Explaining disparities in species richness between Mediterranean floristic regions: a case study in Gladiolus (Iridaceae). Glob. Ecol. Biogeogr. 20, 881-892. doi: 10.1111/j.1466-8238.2010.00644.x

Van Wyk, A. E. (1989). "Floristics of the Natal/Pondoland sandstone forests," in Biogeography of the Mixed Evergreen Forests of Southern Africa, ed C. J. Geldenhuys, 145-157, chtr. 149.

Van Wyk, A. E. (1990). A new species of Leucadendron (Proteaceae) from Pondoland, with a discussion of its biogeography. S. Afr. J. Bot. 56, 458-466.

Venables, W. N., and Ripley, B. D. (2002). Modern Applied Statistics with S, 4th Edn. New York, NY: Springer

Verboom, G. A. (2006). A phylogeny of the schoenoid sedges (Cyperaceae: Schoeneae) based on plastid DNA sequences, with special reference to the genera found in Africa. Mol. Phylogenet. Evol. 38, 79-89. doi: 10.1016/j.ympev.2005.05.012

Verboom, G. A., Archibald, J. K., Bakker, F. T., Bellstedt, D. U., Conrad, F., Dreyer, L. L., et al. (2009). Origin and diversification of the Greater Cape flora: ancient species repository, hot-bed of recent radiation, or both? Mol. Phylogenet. Evol. 51, 44-53. doi: 10.1016/j.ympev.2008.01.037

Verdcourt, B. (1969). The arid corridor between the northeast and southwest areas of Africa. Palaeoecol. Afr. 4, 140-144.

Wang, H. C., Moore, M. J., Soltis, P. S., Bell, C. D., Brockington, S. F., Alexandre, R., et al. (2009). Rosid radiation and the rapid rise of angiospermdominated forests. Proc. Natl. Acad. Sci. U.S.A. 106, 3853-3858. doi: 10.1073/pnas. 0813376106

Weeks, A., and Simpson, B. B. (2007). Molecular phylogenetic analysis of Commiphora (Burseraceae) yields insight on the evolution and historical biogeography of an "impossible" genus. Mol. Phylogenet. Evol. 42, 62-79. doi: 10.1016/j.ympev.2006.06.015 
Weimarck, H. (1933). Die Verbreitung einiger Afrikanisch-montanen Pflanzengruppen, I-II. Sven. Bot. Tidskr. 27, 400-419.

Weimarck, H. (1936). Die Verbreitung einiger Afrikanisch-montanen Pflanzengruppen, III-IV. Sven. Bot. Tidskr. 30, 36-56.

Weimarck, H. (1941). Phytogeographical groups, centres and intervals within the Cape flora. Acta Univ. Lund. Nova Ser. Sect. 2 Med. Math. Sci. Rerum Nat. 37, 3-143.

White, F. (1965). The savanna woodlands of the Zambezian and Sudanian domains. Webbia 19, 651-681.

White, F. (1978). "The afromontane region," in Biogeography and Ecology of Southern Africa, ed M. J. A. Werger (The Hague: Junk), 463-513. doi: 10.1007/978-94-009-9951-0_11

White, F. (1981). The history of the Afromontane archipelago and the scientific need for its conservation. Afr. J. Ecol. 19, 33-54. doi: 10.1111/j.13652028.1981.tb00651.x

White, F. (1983). The Vegetation of Africa. Paris: Unesco.

Wichura, H., Bousquet, R., Oberhansli, R., Strecker, M. R., and Trauth, M. H. (2010). Evidence for middle Miocene uplift of the East African Plateau. Geology 38, 543-546. doi: 10.1130/G31022.1
Wickens, G. E. (1976). The Flora of Jebel Marra (Sudan Republic) and its Geographical Affinities. London: Her Majesties Stationary Office.

Conflict of Interest Statement: The author declares that the research was conducted in the absence of any commercial or financial relationships that could be construed as a potential conflict of interest.

Received: 07 May 2014; accepted: 04 July 2014; published online: 25 July 2014.

Citation: Linder HP (2014) The evolution of African plant diversity. Front. Ecol. Evol. 2:38. doi: 10.3389/fevo.2014.00038

This article was submitted to Evolutionary and Population Genetics, a section of the journal Frontiers in Ecology and Evolution.

Copyright (c) 2014 Linder. This is an open-access article distributed under the terms of the Creative Commons Attribution License (CC BY). The use, distribution or reproduction in other forums is permitted, provided the original author(s) or licensor are credited and that the original publication in this journal is cited, in accordance with accepted academic practice. No use, distribution or reproduction is permitted which does not comply with these terms. 